\title{
Maksymilian Ryło SJ (1802-1848) and the Beginnings of the New Catholic Mission in Africa in Nineteenth Century
}

A mysterious darkness covers until this day the lands extending in the interior of Africa. Governments and private societies took great pains to promote investigation of these territories, organizing well equipped expeditions. Yet, in spite of all these considerable sacrifices and innumerable efforts, not even the border of this impenetrable veil covering them for centuries has been made known -

- wrote in 1860 Gaetano Moroni in his famous dictionary (Moroni 278). ${ }^{1}$ Twelve years earlier had died in Khartoum Maksymilian Ryłło, a forty-six-years old Polish Jesuit to whom is dedicated this article. His life would certainly be interesting enough to inspire a larger historical essay, but the purpose of this contribution is only to remember shortly this outstanding missionary figure, recalling first of all the "African chapter" of his biography and leaving any more complete study to a better pen.

\section{Ryło’s historiography}

Although not completely unknown, Ryłł’s modest historiography could be compared to the knowledge of Africa that the Europeans contemporary to

1 'Un misterioso buio ricopre fino al dì d'oggi que' paesi che nella sua estensione interna l'Africa racchiude. Governi del pari che società private si adoperarono in diverse epoche ad intraprendere indagini intorno a queste terre, allestendo a tal uopo spedizioni ben provvedute. Se non che, malgrado i più considerevoli sagrifizi e innumerevoli sforzi, giammai non si poté levare un lembo a quell'impenetrabile velo che pel volger di tanti secoli vi sta sopra disteso". (Moroni 278). Gaetano Moroni (1802-1883), Italian erudite and writer, he remained for many years in the milieu of Mauro Cappellari, who as Pope appointed him his private secretary; Moroni edited his famous "Dictionary" in 103 volumes, published in Venice in 1840-1861 (Monsagrati 2012). 
him had of this continent, as testifies Moroni: its existence was not ignored since the antiquity, but the real knowledge of it was limited only to its costs used by the Western travellers during their journey towards India and the Far East. The inside of Africa remained mysterious and unknown, thus the name of the "Dark Continent" sometimes attributed to the lands otherwise described with the expressions to be found in the old maps saying Hic sunt leones (here are lions).

In fact, any scholar interested in Ryłło could easily realize - only looking at the existing bibliographies (for example, Sommervogel 1896, 343-344 and Sommervogel 1932, 1889-1890) and other tools of research usually used at the beginning of each historical query - that the famous missionary has quite a limited historiography. There are articles in encyclopaedias and dictionaries, both general (Testore 152; Grzebień 1992, 504-506; Bieś 675-676) and those dedicated to the Jesuits (Jalabert 1987b, 367-368; Jalabert 2001b, 3452; Encyklopedia wiedzy o jezuitach 589), while the purpose of few other contributions was to briefly introduce Ryłło and his activities. Some of these studies concern precisely the beginnings of the mission in Central Africa (e.gr. Storme 1952, 105-118; Storme 1953, 290-305; Schmid, 109-127).

As for more recent publications, László Polgár indicates all together fourteen titles: three books, three entries in encyclopaedias and eight articles or contributions to larger works (usually concerning the missionary history) where there is question of Ryłło (Polgár 119-120). ${ }^{2}$ From all these publications, six are in Polish, three in French and in Italian, one in Flemish and Lithuanian. Four other titles in Polish are added to this list by the recent bibliography edited by Ludwik Grzebien (Grzebień 2009, 223-224). Thus, the English speaking reader risks to be disappointed not finding in these bibliographies anything in the language of Shakespeare. ${ }^{3}$

The available publications represent two literary genres: (1) popular books or articles (Czermiński; Kantak; Karol); (2) academic works (Storme 1952; Storme 1953; Schmid).

As for Polish authors, they often focused on such particular aspects of the famous Jesuit's life as patriotic- and national dimensions of his activities. Some scholars were interested in his meetings and relationship with outstanding Polish writers of that time, or just in introducing Ryłł to their readers, whose number remains limited to those who are able to read Polish (only Kantak wrote his book in French). In regard to that point, there are no changes between what pushed Czermiński hundred years ago to write about the famous

${ }^{2}$ For the years after 1980, see also the appendix to this bibliography published in the Roman periodical of the Jesuit Historical Institute, Archivum Historicum Societatis Iesu.

${ }^{3}$ However, one must notice Mkenda 2013. 
missionary, and what must have been motivation of Kantak and Karol to do the same in 1950 and in 1992.

Having seen all that, one must recognize that the most extensive and more complete biography of Ryłło remains until the present day the work of Czermiński, ${ }^{4}$ while the contribution of Schmid provides the most useful introduction to the "African chapter" of his life. Being this last work an academic study, it is also helpful enough from the methodological point of view: the author quotes with precision both literature and archival sources, which is not always the case of his predecessors writing about Ryłło.

Indeed, the book by Czermiński, though popular, is also based on archival sources, including many large translations of these documents into Polish. However, the usual indication of the sources quoted as "Archiv. S. I." will hardly satisfy contemporary historians. Yet, they have to remember that at that time the Jesuit Roman Archives (Archivum Romanum Societatis Iesu, usually abbreviated as ARSI), which are quoted in this way, remained divided in two parts: the older one had been secretly sent from Rome to Netherlands in 1893 in order to avoid its confiscation by the Italian government, while the more recent documentation (including the texts quoted by Czermiński) followed the Society's General Curia, expelled from the Eternal City in 1873 and established in Fiesole. Concerned with the protection of these archives the General of the Society of Jesus ordered in 1896 that the authors who quote them should do it only very generally and avoiding giving details of their location. ${ }^{5}$ Obeying these orders Czermiński could have hardly given more information in his two volumes.

\section{Ryło's life}

The existing literature dispenses from any longer biographical introduction of Ryłło. On the other hand, both his life and historiography correspond to what Moroni wrote concerning the knowledge of Africa, as expressed in the quotation opening this article. Indeed, Ryłł's life is known in its outlines well enough, yet there are many points where this knowledge remains not satisfac-

${ }^{4}$ Marcin Czermiński (1860-1931, Jesuit from 1885), between 1889 and 1919 he was chief editor of the missionary periodical of the Polish Jesuits Misje Katolickie, and thus became author of many popular studies about Jesuit missionaries (Encyklopedia wiedzy o jezuitach 111). According to Czermiński there were plans to publish some "Life" of Ryłło in other languages (Czermiński 1: IX). Apparently it was never realized.

${ }^{5}$ See the circular letter by Luis Martín from December 7, 1896, confirmed by his successor Franz Xaver Wernz on January 30, 1911 (Wernz). Luis Martín (1846-1906, Jesuit from 1864), Spaniard, he was elected General in 1892 (Sanz de Diego). Franz Xaver Wernz (1842-1914, Jesuit from 1857), German, he was elected General in 1906 (Martina). 
tory while several questions require a deeper study, although doubts remain whether any further sources could be found to complete what have already been said.

Stanisław Maksymilian Ryłło was born in Podorosk near Grodno (Belarus), 31 December 1802 (some authors, who remind the difference of twelve days between the Julian and the Gregorian calendar, proposed the date of 11 January $1803 ; ;^{6}$ however, the first date prevails in the historiography and also appears in the Jesuit catalogues).

After having attended the school in the neighbouring town Łysków, he was sent to the Jesuit college in Połock, where he was certainly in 1817. As noticed by the authors who wrote about Ryłło, only few details from these years of his youth are known and possible to establish thanks to several testimonies. Apparently, there are few chances to complete this chapter of the Jesuit's biography, given the lack of documents, understandable because of the vicissitudes that this area had to endure since that time. What is doubtless is that the future missionary attended the school that the Society had in Połock, where he must have spent around two years. From there he moved to the University of Wilno (Vilnius) where he might have started to study medicine shortly before the fatal year 1820 which gave a new orientation to the rest of his life.

That year the Society of Jesus, which up to that time had survived in the Russian Empire after the Clementinian suppression of 1773, was expelled from that country. When the Jesuits were about to leave, young Ryłł joined them having already decided to enter the Order. Thus, trough Vienna he arrived to Rome in August 1820 and there entered the noviciate at Sant'Andrea al Quirinale the next 9 September. After the two-years noviciate followed by a short period of literary studies), the "scholastic" Ryłło left this Roman house for the next stage of his formation, called "regency" which consisted in teaching in one the Order's colleges. ${ }^{7}$ For this purpose, he was sent to Orvieto, where he must have arrived at the end of 1822 or at the beginning of 1823. A year later, he was back in the Eternal City to study philosophy in the Roman College, where he spent two years, i.e. 1824-1826. His next mission was teaching humanities, catechism and working as prefect of students in the Jesuit colleges in Novara (1826-1827) and Turin (1827-1830). Once again back to Rome in 1830, he attended four years programme of theology at the Roman College and was ordained priest 29 December 1833. Directly after studies, he completed his formation doing the so-called "tertianship" at the Roman house of Sant'Eusebio (1834-1835) and took his final vows 2 February 1838 at the altar of Saint Ig-

\footnotetext{
${ }^{6}$ For example, Bano 117 (quoted after Schmid 109).

${ }^{7}$ About the meaning of the words as "scholastic" or "regency", see The Cambridge Encyclopedia of the Jesuits 672-673, 721 .
} 
natius in the Gesì church, as testifies their formula preserved in the archives (ARSI, Assistentia Italiae. Vota Professorum 1814-1850, 178 $\left.-179^{\mathrm{r}}\right) .{ }^{8}$

His first mission after the tertianship was pastoral work in the Caravita Oratory and teaching philosophy in the Roman College (the academic year 1834-1835). At the same time, he preached retreats in diverse churches of the City - the apostolate that he had started already as scholastic and in which he was very successful from the beginning.

Some of the scholars writing about Ryłło attribute to the same time his plan to come back to his native country as missionary, a desire that he would have expressed to Father General Roothaan, whom he must have known personally from Połock and Turin (Karol, 26-28). ${ }^{9}$ Here there are considerable differences between the authors. According to Czermiński, Ryłło would have tried to obtain a passport from the Russian ambassador in Rome, but without success (understandable in the context of the recent Polish uprising against Russia in 1830-1831); he would also asked Roothaan a permission to come back to his native country, but the General would not accept this request given the circumstances (Czermiński 1: 54-55). Yet, Czermiński (or rather the authors that he quotes, i.e. Zaleski, 61-64) must have confused something: the ambassador Butenev ${ }^{10}$ was at his post in Rome only in 1843, thus either Ryłł asked him a passport at that time (not very probable) or he had asked it when the diplomat was still in Constantinople. In any case, there is some confusion between the sources concerning this point.

Furthermore, Carlo Tappi affirms that the Jesuit had a short journey to Russia with a special mission which he locates somewhere after Ryłł's ordination and 1836, while Czermiński and Kantak affirm that after 1820 he never entered his country again (Tappi, 77 [quoted after Schmid, 109]; Czermiński 1: 55; Kantak, 21). This last version appears more probable, given also the fact that Tappi does not indicate the sources of his statement, which appears not very convincing, also looking at too much liberty that this author takes in reporting some other biographical details about the Jesuit, especially those related to his native country and the first stages of his live. After all, after 1820 the members of the Society of Jesus were not welcome Russia and, as show other examples from the posterior years, it was all but easy to obtain permission to obtain the permission to enter that country.

\footnotetext{
${ }^{8}$ About the meaning of the word "tertianship" and about the significance of the Jesuit final vows, see The Cambridge Encyclopedia of the Jesuits 345, 652-653, 780.

${ }^{9}$ Jan Philip Roothaan (1785-1853, Jesuit from 1804), Dutch, he was elected General in 1829 (Chappin).

10 Apollinarij Petrovič Butenev/Аполлинарий Петрович Бутенев (1787-1866), Russian diplomat, ambassador in Constantinople in 1830-1842 and then in Rome for ten years from 1843 (Russkij Biografičeskij Slovar'518).
} 
Eventually, instead of Russia, Ryłło was sent to Middle East. He was interested in the missions already during the first years of his religious life. The archives preserve his letter to Fr. General Fortis in which he volunteered for missions in the Aegean Sea (Assistentia Italiae. Missiones Petentes). ${ }^{11}$ At that time, he was still a scholastic and had to finish his training. Before it happened, the Jesuits started a new mission in Lebanon in 1831. It was led by Ryłło's older fellow student from the Roman College, Paolo Maria Riccadonna. ${ }^{12}$ As notices Czermiński, both maintained a regular correspondence and Ryłło sent to his colleague some money that he was able to collect for the needs of this mission. Since 1833 the Polish Jesuit would have volunteered for this mission and for that purpose he even learned some Arabic (Czermiński 1: 44, 57). Thus, when in 1836 the Pope Gregory XVI asked Roothaan to give him somebody for a special mission that he wanted to entrust to the Jesuits (the recognition of the situation in Mesopotamia where internal problems of the Christians and possible perspective of reconciliation with the Nestorians required an initiative of the Holy See), the General chose Ryłło.

He left Rome in June 1836 and through Florence and Cyprus arrived to Beirut in September. At the end of the same year, he traveled with Riccadonna to the Holy Land where they spent several weeks. In March 1837 both left Beirut for Mesopotamia. Through Damascus, Homs and Aleppo they arrived to Mossoul at the end of June and spent there circa one month. To accomplish their mission they had to prepare a rapport for Rome where Ryłło returned the last days of December of the same year. Actually, he submitted two reports to the Roman authorities: the one about the situation in Syria and Mesopotamia, the other one with the idea of funding a college in Middle East. This second plan preceded his first journey, as reports Czermiński quoting Ryłło's letter to the General from 7 June 1836 with summaries of his conversations with Cardinal Fransoni (Czermiński 1: 58-59). ${ }^{13}$

Given that the Pope Gregory XVI accepted the plan of the new college, the Jesuit left again for East in June 1839. He stopped in Malta and then in Constantinople where he had successful experience of preaching and at the end of August arrived to Beirut. Shortly after, he became superior of the Syria

${ }^{11}$ The letter is without date, but it must have been written in the early 1820-ties for Ryło refers to the death of Domenico Venturi (1765-1823, Jesuit from 1801), Italian, missionary at Syros, which occurred 12 March 1823 (Mendizábal 8 [nr 386]). Luigi Fortis (1748-1829, Jesuit from 1762), Italian, he was elected General in 1820 (Padberg).

${ }^{12}$ Paolo Maria Riccadonna (1799-1863, Jesuit from 1818), Italian, he was the first superior of the new Mission of Syria (Jalabert 2001a).

13 Giacomo Filippo Fransoni (1775-1856), Italian, bishop in 1822 and cardinal in 1826, from 1834 he was Prefect of the Propaganda Fide (Monsagrati 1998). Czermiński published also a summary of this project and the Polish translation of it (Czermiński 1: 154-157; 321-334). The Italian original in preserved in ARSI, Proximi Orientis. 
Mission and acting Apostolic Delegate for Syria and Lebanon. He managed to open a school Beirut in 1841, but a complicated political situation in the area, which would be too long and out of purpose to discuss here, brought the General Roothaan to the decision to call Ryłło back. In 1842 the school that he started was transferred to Ghazir and only later, in 1875, a new university opened in Beirut according to what were wishes of the Polish Jesuit in whom this institution sees its fonder.

Ryłło left Lebanon in September 1841 and moved to Malta where he stood until September 1843. His successful preaching there as well as more and more real perspective of a permanent presence of the Jesuits in the island made that liberal milieus with some members of the local Catholic hierarchy were against him. In result of that he was forbidden to preach and eventually had to leave the island for near Sicily. Between September 1843 and June 1844 he dedicated himself to preaching in diverse places there and was once again very fortunate in this ministry.

In June 1844 he was called to Rome and appointed rector of the Collegium Urbanianum of the Propaganda, the charge he had until September 1846, when he had to leave for his next and last mission, this time in Africa.

\section{The "African chapter"}

The "African chapter" of Ryłł’’s life opened in a very particular historicalecclesiastical context. At the time of the great renewal of Catholic missions under Gregory XVI, a Maltese canon Annetto Casolani, interested in missionary problematic, was charged by the Propaganda Fide in 1844 to write a project of a new mission in Africa. ${ }^{14} \mathrm{He}$ might have got in touch with this dicastery already earlier, but first had not received any answer to his general proposals. Having read a report from the journey to Africa made in 1838-1839 by a Czech trade man Ignaz Pallme (Pallme 1843; Pallme 1844), Casolani submitted a new project to the Propaganda in 1845. When Rome was interested on promoting his initiative and asked his personal participation in it, the canon asked to have help of the Jesuits. ${ }^{15}$ Thus, 22 August 1845 the Propaganda asked Roothaan to choose assistants for Casolani (ARSI, Assistentia Africae 1001-I-3). The General first answer from 3 September 1845 was negative: he had no people to offer. However, the day after he added to his letter a note with

${ }^{14}$ Annetto Casolani (1815-1866), Maltese, bishop and Vicar Apostolic of Central Africa in 1846, he resigned from this last function and accompanied the missionary expedition led by Ryłło (Hierarchia Catholica 257).

${ }^{15}$ See letters of the Propaganda to Casolani from 12 July 1845 and the answer of the latter from 5 August 1845, both published in Storme 1952, 110-111. 
the proposal of organizing an exploration journey in Africa before establishing any permanent mission. For such a journey his only candidate was Ryłło. ${ }^{16}$

At the beginning of 1846 Gregory XVI approved the proposal of the Propaganda to create a new Apostolic Vicariate of the Central Africa. ${ }^{17}$ It should include territories between Red Sea, Egypt, Ethiopia, Tripolitania and Guinea, i.e. more towards East as originally Casolani had proposed. The Maltese canon was appointed Apostolic Vicar and, given that their journey should be not only an explorative expedition, but at the same time a starting point of the new permanent mission, he was ordained bishop.

These origins of the new Apostolic Vicariate are known and resumed by already quoted Erich Schmid, who based on the works of earlier historians completed their achievements by further research in the archives. In what concerns Ryłło, he left Rome for Africa in October 1846 and through Malta and Lebanon arrived to Alexandria in April 1847 in order to meet the rest of the missionary group as planned. Here started surprises: Casolani resigned from his post and the Pope appointed Ryłł his successor and Pro-Vicar of the new mission. At that news Roothaan protested noticing that the Polish Jesuit had no talent for administration, but he was answered that this appointment was only temporary. Yet, the General judged convenient to send Fr. Pedemonte to be Ryłło’s “Angel Guardian” for administrative tasks. ${ }^{18}$

In July 1847 the missionary team was complete. Besides his fellow Jesuit, Ryłł had as assistants two priests: a Slovenian Ignaz Knoblecher and an Italian Angelo Vinco, and... Casolani himself, who wanted to participate in the mission as its simple member. ${ }^{19}$ They left Alexandria for Cairo and from there sailed south along Nil. Unfortunately Ryłł started this journey already sick of dysentery, circumstance that obliged them to go on slowly and to have enough time for rest.

11 February 1848 they arrived to Khartoum and started to organize there a new missionary centre. Ryłło never entirely recovered from his illness. Yet, he managed to buy a house with a garden and to open a chapel and a small school for orphans and children of Christians. Seriously ill and not being able

${ }^{16}$ See Roothaan's answer to the Propaganda from 3-4 September 1845, published in Storme 1952, 111-112; the same author published also other important documents concerning the origins of the Jesuits involvement in this mission.

${ }^{17}$ See the decree of its canonical erection published in Schmid 315.

${ }^{18}$ Emanuele Pedemonte (1792-1867, Jesuit from 1818), Italian, he belonged to the Province of Naples (Mendizábal 60 [nr 3.327]).

${ }^{19}$ Ignaz Knoblecher (1819-1858), ordained priest in 1845, he was then the head of the new mission (Aubert). Angelo Vinco (1819-1853), Italian, priest in 1844, he was destined to accompany the same expedition; in 1849 he was back in Italy to organize funds for the new mission where he returned and where he died after having accomplished several journey of missionary exploration (Zaghi). 
to explore the area as planned, he asked his General and the Propaganda to send him money and new assistants, both necessary for facing the tasks the immensity of which he started to realize more and more.

Four months and a few days lasted the stay of Ryłło in Khartoum. During this short time which certainly was all but easy given the circumstances and his health, the Jesuit sent to several addresses in Europe at least three letters which survived the vicissitudes and give testimony of his missionary plans as well as of his first impressions of the unknown territories and their inhabitants, his plans and fears, etc.

The first letter is from April 6, 1848 and was the last that Ryłło wrote to his General in Rome. The original of it is preserved in the Roman Jesuit Archives (ARSI, Assistentia Africae 1001-II-2), while a Polish translation has been published by Czermiński (Czermiński 2: 288-293). The second letter dates from April 10, 1848 and was sent to the French Oeuvre de la Propagation de la Foi in Lyon. It has been published as well (Ryłło 1848c; Ryłło 1901a). ${ }^{20}$ The third one, from April 19, 1848, which seems to be the last written by Ryłło, was destined to Cardinal Fransoni. Also this letter has been published (Ryłło 1848a). ${ }^{21}$

Looking at these texts one can easily discover all characteristics of the Jesuit missionary literature. Indeed, the members of the Society of Jesus were obliged to follow a particular way of proceeding while writing to their superiors or other addressees. Already the Founder of the order gave to his first companions quite detailed instructions concerning their official and missionary correspondence. ${ }^{22}$ These prescriptions were improved in the following years and were followed by the Jesuits also in nineteenth century. Although in this point Ryłło was all but exception, his letters are instructive enough to deserve our attention.

First off all, conforming to the above mentioned rules, he gave some general description of the territory, which at that time remained almost unknown to the Europeans. He wrote to his General namely:

The island of Sennar extends between two rivers, or to say it better, between two branches of the same river Nile, which because of the difference of the colour of water takes two different names: Blue Nile and White Nile. Its capital is Khartoum built in the spit after the Egyptian occupation, and succeeding the other,

\footnotetext{
${ }^{20}$ According to Czermiński and the editors of the Lettres, the Italian original of this letter was in the archives of this association in Lyon (Czermiński 2: 286; Ryłło 1901a, 459).

${ }^{21}$ French translation: Ryłło 1848b and Ryłł 1901b. Polish translation: Czermiński 2: 294-302. The editors do not indicate where the original of this letter was preserved.

${ }^{22}$ I tried to resume the origins and the characteristics of this system in a paper "From Manuscript to Print: At the Origins of Early Jesuit Missionary Strategies of Communication" delivered during a conference at San Francisco University in September 2010 (publication forthcoming).
} 
more ancient and homonymous, distant some days along the White River. Hitherto the Islam did not progress a lot here, and at the distance of three, six or no more than ten days of walk along one or other river, live pagan tribes of Africans (ARSI, Assistentia Africae 1001-II-2). ${ }^{23}$

All that corresponds perfectly to the exigencies of the Jesuit missionary relations from each time. They were asked to describe territories they were entering, including observations about the lands, its geography, climate, its plants and animals, etc. All that concerning Africa was as interesting for the European public in nineteenth century, as it had been in sixteenth and seventeenth centuries concerning Asia or South America. Concerning this point, particularly suggestive is also Ryłł’s description of the Mass that his missionary group had in the Island of Philae, in the ruins of the temple of Isis:

In the morning, we crossed the river in a small boat and at the rising of sun we were in the temple of Isis changed in a Christian church in sixth century by bishop Gregory. When Muslim sword exterminated the Christianity in Nubia, the church turned into ruins, as many other monuments that are still visible here. We installed a portative altar and bishop Casolani wearing sacred vestments started a Mass to which we attended with all our hearts. The Solitude, the silence and the place where we were, all that filled our souls with sweetness and consolation which are difficult to express, and which one could hardly find even in the midst of pompous ceremonies in the most splendid churches (Ryłło 1901a, 457). ${ }^{24}$

This text sent to an association helping the Catholic missions was certainly more than appropriate to wake up the zeal and the generosity of potential benefactors whose help was so necessary. At the other hand, the Polish Jesuit was all but a poet, who would easily touch hearts of his readers by the force of

23 "L'isola di Sennar giace fra due fiumi o per dir meglio fra due rami d'un solo fiume che è il Nilo, il quale nella sua diramazione dal diverso colore delle sue acque prende il nome di Nilo bianco e Nilo turchino. Khartum n'è la capitale sorta alla punta dell'isola dopo l'occupazione egiziana, e succeduta all'antica omonima all'isola e posta più in su alcune giornate sul fiume bianco. L'islamismo fin ora non ha fatto grandi progressi, ed alla distanza di tre, sei o al più dieci giornate di cammino sull'uno e l'altro fiume incominciano le tribù idolatre dei Neri'. The translation is mine.

24 "Donc le matin, à l'aube du jour, nous nous mîmes dans une petite barque, pour traverser le fleuve, et, au lever du soleil, nous étions dans le temple d'Isis, converti en église chrétienne au $\mathrm{VI}^{\mathrm{e}}$ siècle par l'évêque Grégoire. Le christianisme ayant été détruit dans la Nubie par l'épée des mahométans, cette église tomba en ruines comme tous les autres monuments dont il reste encore aujourd'hui les débris. Un autel portatif fut érigé et Mgr Casolani, ayant revêtu les habits sacrés, commença la sainte Messe, tandis que nous l'accompagnions de cœur. La solitude, le silence, le lieu où nous étions, tout remplissait notre âme d'une douceur et d'une consolation ineffables, que l'on éprouve rarement au milieu des splendeurs du culte, dans les temples les plus grandioses". The translation is mine. 
images and other rhetoric figures. Contemporary to the above quoted text, he wrote to his General:

My Father, abstract ideas about difficulties of missionary work, formed upon lecture of stories and sometimes romantic letters of missionaries, are different thing than a practice made in a school of suffering and privations (ARSI, Assistentia Africae 1001-II-2) 25 .

Ryłło also included in his letters some information about the people living in these territories, stressing on their simplicity and openness towards the Christian religion which, according to him they would easily accepted. He described them as pacific, rural population living in villages and dedicated to agriculture and raising animals. Actually, in order to convince the General of the necessity of accepting this new mission and sending to it new Jesuits, he compared the situation he was witness of to the famous missionary initiative of the Society of Jesus in Paraguay in the previous centuries:

Simple people, true children of the nature, and not difficult in following anybody who would show concern for their good and who would introduced them to the Christian civilisation. All together, they are less distant from the conversion than the savage people of America, for they live more or less organized in villages, and are familiar with farming and agriculture, as Your Paternity will be convinced from some of their arms and tools that I send for the Museum Kircherianum. [...] This mission could turn into a new Paraguay [...] (ARSI, Assistentia Africae 1001-II-2). ${ }^{26}$

\section{Conclusion}

All these letters testify of big enthusiasm, but also a preoccupation of their author concerning the new mission. He realized how difficult this enterprise is and how much should be done to succeed. He very concrete proposal was to open three missionary stations in the area, continuing already started apostolate in the capital. For all that he desperately needed help from Europe, namely men and money, and for such help was asking all his addressees. Unfortunately, he could not witness the arrival of this so desired help.

25 "Padre mio, altro sono le idee astratte sulle arduità delle missioni, formate colla lettura delle storie e talvolta delle lettere romantiche dei missionari, altro la pratica fattasi alla scuola dei patimenti e delle privazioni". The translation is mine.

26 “Popoli semplici, veri figli della natura e non difficili a seguir chiunque si mostrasse premuroso del loro bene e li introdusse alla civilizzazione cristiana. Sono in somma meno lontani dall'esser ridotti dai selvaggi dell'America, in quanto che vivono per lo più riuniti nei villaggi, attendono alla pastorizia ed hanno principi delle arti e dell'agricoltura, come V. P. potrà convincersene dall'invio che le fo pel Museo Kircheriano di alcune loro armi ed utensili. [...] Potrebbe diventare questa missione un nuovo Paraguay [...]". The translation is mine. 
The exhausted missionary died 17 June 1848 and was buried in the garden of the Mission (only in May 1900 his body was transferred from Khartoum to Cairo and deposited in the Jesuit vault). However, the mission that he started has continued. Shortly before Ryłł’s death, he appointed Knoblecher his successor. When Casolani and Vinco left for Europa, only Knoblecher and Pedemonte remained in Sudan and so it was until March 1849 when three new Jesuits arrived. Already in April 1848 Ryłł had asked Cardinal Fransoni to obtain from Roothaan four Jesuit Fathers and four Brothers for the new mission. In June of the same year Casolani asked the General for two Fathers and one Brother. Answering this request, Roothaan destined Fathers Zara and Repetti, and Brother D'Ottavio. ${ }^{27}$ They arrived to Khartoum in March 1849, but three years later, the same General ordered them to leave Sudan. Eventually the Jesuits were replaced by other missionaries (Otto 237-248).

Although all these episodes are not unknown, there are certainly questions to deepen as, e. gr. the reasons of the extension of the territories of the new Apostolic Vicariate, the change of the starting point and the route of the planned journey, or the circumstances of the renunciation of Casolani. The diversity of opinions among the authors writing about these themes does not change tha fact that there is also a progress in the knowledge of this history, especially watching the works of Storme and Schmid excluding less probable or rather surely erroneous interpretations as the one attributing the decision of Casolani to resign to a presumed conflict that he would have had with Ryłło and to the fact that the Propaganda would have preferred what the Jesuit was proposing concerning the missionary journey (Storme 1953, 290-292).

The literature quoted in the first part of this article as well as the archives, especially these of the Propaganda and the Jesuit Roman Archives, shall certainly help in such attempt of deepening the knowledge of this extraordinary missionary in whose case remains valid (unfortunately!), at least to a certain extent, what has been said in 1901: "It is a pity that Fr. Ryllo has not have a historian” (,Le P. Maximilien Ryllo” 452). ${ }^{28}$

\section{A B S T R A C T}

The Polish Jesuit Maksymilian Ryłł (1802-1848) participated in several missionary endeavors undertaken by the Church in nineteenth century and entrusted to the

${ }^{27}$ Gaetano Zara (1819-1853, Jesuit from 1837), Italian, member of the Province of Venice (Jalabert 1987a). Giuseppe Repetti (1810-1895, Jesuit from 1835), Italian, member of the Roman Province (Mendizábal 155 [nr 8.619]). Francesco D’Ottavio (1805-1859, Jesuit from 1825), Italian, member of the Roman Province (Mendizábal 44 [nr 2.419]).

28 “Il est à regretter que le P. Ryllo n'ait pas eu d'historien". The translation is mine. 
Society of Jesus. Besides his missions in Middle East in 1836-1837 and 1839-1841, he was also one of the protagonists of an exploratory trip to North East Africa started in 1847 from Egypt and directed south. Arrived to Khartum and established there for a few months, Ryłło died in that city, while a few years later other missionaries took over the work of evangelization started by him and his companions. The present article introduces this Jesuit and focuses on the "African chapter" of his life - all as an attempt of filling the historiographical gap consisting in the fact that the English literature about Ryło is almost inexistent.

Keywords: Ryłło Maksymilian; Jesuits; $19^{\text {th }}$ century; foreign missions; Africa

Słowa kluczowe: Ryłło Maksymilian; jezuici; XIX wiek; misje zagraniczne; Afryka

\section{BIBLIOGRAPHY}

Archivum Romanum Societatis Iesu (ARSI):

- Assistentia Africae 1001-I-3

- Assistentia Africae 1001-II-2

- Assistentia Italiae. Vota Professorum 1814-1850, f. 178 $\mathrm{r}-179^{\mathrm{r}}$

- Assistentia Italiae. Missiones Petentes 1816-1844

- Proximi Orientis 1001-IX-1

Aubert, Roger. „Knoblecher (Ignaz).” Dictionnaire d'Histoire et de Géographie Ecclésiastiques. T. 29. Paris: Letouzey et Ané, 2007. 368-369.

Bano, Leonzio. Mezzo secolo di storia sudanese (1842-1898). Bologna: Editrice Missionaria Italiana, 1976.

Bieś, Andrzej Paweł. „Ryłło Maksymilian.” Encyklopedia Katolicka. T. 17. Lublin: Towarzystwo Naukowe Katolickiego Uniwersytetu Lubelskiego Jana Pawła II, 2012. 675-676.

The Cambridge Encyclopedia of the Jesuits. Cambridge/New York: Cambridge University Press, 2017.

Chappin, Marcel. „Roothaan, Juan Felipe.” Diccionario Histórico de la Compañía de Jesús. Biográfico-temático. Vol. II. Roma: Institutum Historicum S.I.; Madrid: Universidad Pontificia Comillas, 2001. 1665-1671.

Czermiński, Marcin, O. Maksymilian Ryłlo Towarzystwa Jezusowego, Misyonarz Apostolski. 2 vols. Kraków: Czcionkami Drukarni 'Czasu’, 1911-1912.

Encyklopedia wiedzy o jezuitach na ziemiach Polski i Litwy 1564-1995. Ed. Ludwik Grzebień. Kraków: Wyższa Szkoła Filozoficzno-Pedagogiczna Ignatianum/Wydawnictwo WAM, ${ }^{2} 2004$.

Grzebień, Ludwik. „Ryłło Maksymilian Stanisław.” Polski Słownik Biograficzny. T. 33. Wrocław/ Warszawa/Kraków: Polska Akademia Umiejętności/PAN/Ossolineum, 1992. 504-506.

Grzebień, Ludwik. Podstawowa bibliografia do dziejów Towarzystwa Jezusowego w Polsce. T. 2. Kraków: Wydawnictwo WAM/Wyższa Szkoła Filozoficzno-Pedagogiczna „Ignatianum”, 2009.

Hierarchia Catholica Medii et Recentioris Aevi. Vol. VII. Eds. Remigius Ritzler, Pirminus Sefrin. Patavii: Typis et Sumptibis Domus Editorialis "Il Messaggero di S. Antonio", 1968.

Jalabert, Henri. „P. Gaétan Zara.” Jésuites au Proche-Orient. Notes biographiques. Beyrouth: Dar El-Machreq Sarl, 1987. 5.

Jalabert, Henri. „P. Maximilien Ryllo.” Jésuites au Proche-Orient. Notes biographiques. Beyrouth: Dar El-Machreq Sarl, 1987. 367-368. 
Jalabert, Henri. „Riccadonna, Paolo-Maria.” Diccionario Histórico de la Compañía de Jesús. Biográfico-temático. Vol. IV. Roma: Institutum Historicum S.I.; Madrid: Universidad Pontificia Comillas, 2001. 3349-3350.

Jalabert, Henri. „Ryłło, Maksymilian.” Diccionario Histórico de la Compañía de Jesús. Biográfico-temático. Vol. IV. Roma: Institutum Historicum S.I.; Madrid: Universidad Pontificia Comillas, 2001. 3452.

Kantak, Kamil. Le Père Maximilien Ryllo S.J. Un ami du Proche-Orient. L'homme aux grandes visions, mort à la peine. Beyrouth: [s.n.], 1950.

Karol, Andrzej. Jezuita romantyczny. O. Maksymilian Ryłlo. Kraków: Wydawnictwo Apostolstwa Modlitwy, 1992.

„Le P. Maximilien Ryllo Provicaire Apostolique de l'Afrique centrale. Notes recueillies à l'occasion du transport de ses restes de Kartoun au Caire, au mois de mai 1900." Lettres de Fourvière 7 (January 1901) : 452-474.

Martina, Giacomo. „Wernz, Francisco Javier.” Diccionario Histórico de la Compañía de Jesús. Biográfico-temático. Vol. II. Roma: Institutum Historicum S.I.; Madrid: Universidad Pontificia Comillas, 2001. 1682-1687.

Mendizábal, Rufo. Catalogus defunctorum in renata Societate Iesu ab a. 1814 ad a. 1970. Romae: apud Curiam P. Gen., 1972.

Mkenda, Festo. Mission for Everyone. A Story of the Jesuits in Eastern Africa (1555-2012). Nairobi: Paulines Publications Africa, 2013.

Monsagrati, Giuseppe. „Fransoni, Giacomo Filippo.” Dizionario Biografico degli Italiani. Vol. 50. Roma: Istituto della Enciclopedia Italiana Fondata da Giovanni Treccani, 1998. 254-256.

Monsagrati, Giuseppe. „Moroni, Gaetano.” Dizionario Biografico degli Italiani. Vol. 77. Roma: Istituto della Enciclopedia Italiana Fondata da Giovanni Treccani, 2012. 83-87.

Moroni, Gaetano. Dizionario di erudizione storico-ecclesiastica da S. Pietro sino ai nostri giorni. Vol. XCVIII. Venezia: Dalla Tipografia Emiliana, 1860.

Otto, Joseph Albert. Gründung der neuen Jesuitenmission durch General Pater Johann Philipp Roothaan. Freiburg im Breisgau: Herder, 1939.

Padberg, John W. „Fortis, Luis.” Diccionario Histórico de la Compañia de Jesús. Biográfico-temático. Vol. II. Roma: Institutum Historicum S.I.; Madrid: Universidad Pontificia Comillas, 2001. $1662-1665$.

Pallme, Ignaz. Beschreibung von Kordofan und einigen angränzenden Ländern. Stuttgart: J. G. Cotta, 1843.

Pallme, Ignaz. Travels in Kordofan: Embracing a Description of That Province of Egypt and of Some of the Bordering Countries, with a Review of the Present State of the Commerce in Those Countries. J. Madden and Co, 1844.

Polgár, László. Bibliographie sur l'histoire de la Compagnie de Jésus, 1901-1980. Vol. III***: Les Personnes. Roma: Institutum Historicum Societatis Iesu, 1990.

Russkij Biografičeskij Slovar'. T. 3. Sankt-Peterburg: Tipografija, Glavnago Upravlenija Udelov, 1908.

Ryłło, Maksymilian. „[Letter to card. Fransoni, 19 April 1848].” Giornale Romano. 16 September 1848.

Ryłło, Maksymilian. „[Letter to card. Fransoni, 19 April 1848].” Ami de la Religion. 30 September 1848.

Ryłło, Maksymilian. „[Letter to Oeuvre de la Propagation de la Foi, 10 April 1848].” Annales de la Propagation de la Foi (1848) 20: 449.

Ryłło, Maksymilian. „[Letter to Oeuvre de la Propagation de la Foi, 10 April 1848].” Lettres de Fourvière (1901) 7: 456-459.

Ryłło, Maksymilian. „[Letter to card. Fransoni, 19 April 1848].” Lettres de Fourvière (1901) 7: 459$-463$.

Sanz de Diego, Rafaél. „Martín García, Luis.” Diccionario Histórico de la Compañía de Jesús. Biográfico-temático. Vol. II. Roma: Institutum Historicum S.I.; Madrid: Universidad Pontificia Comillas, 2001. 1676-1682. 
Schmid, Erich. Alle origini della Missione dell'Africa Centrale. [Verona]: Novastampa di Verona, 1987.

Sommervogel, Carlos. Bibliothèque de la Compagnie de Jésus. Vol. VII. Bruxelles: Schepens; Paris: Picard, 1896.

Sommervogel, Carlos. Bibliothèque de la Compagnie de Jésus. Vol. XI. Ed. Pierre Bliard. Paris: Picard, 1932.

Storme, Marcel. „Origine du Vicariat Apostolique de l'Afrique Centrale.” Neue Zeitschrift für Missionswissenschaft (1952): 105-118.

Storme, Marcel. „La Rénonciation de Mons. Casolani, Vicaire Apostolique de l'Afrique Centrale.” Neue Zeitschrift für Missionswissenschaft (1953): p. 290-305.

Tappi, Carlo. Cenno storico della Missione dell'Africa Centrale. Torino: Tipografia Salesiana, 1894.

Testore, Celestino. „Ryllo, Maksymilian.” Enciclopedia Cattolica. Vol. X. Città del Vaticano: Ente per l'Enciclopedia Cattolica e per il Libro Cattolico, [1953]. 1502.

Wernz, Franz Xaver. „Ad omnes Praepositos Provinciarum. De Tabulario Societatis [letter from 30 January 1911].” Acta Romana Societatis Iesu 1.3 (1911): 48-49.

Zaghi, Carlo. „Vinco, Angelo.” Enciclopedia Italiana, Appendice I. Roma: Istituto della Enciclopedia Italiana Fondata da Giovanni Treccani, 1938. 1129.

Zaleski, Józef Bohdan. Korespondencya. T. 5. Lwów: Nakładem Wydawcy, 1904.

Robert Danieluk SJ, ur. 1969, ukończył studia historyczne na Papieskim Uniwersytecie Gregoriańskim w Rzymie (licencjat w 1999) oraz École Pratique des Hautes Études w Paryżu (doktorat 2004), specjalizując się w historii jezuitów. Od 2004 jest pracownikiem Rzymskiego Archiwum Towarzystwa Jezusowego. 